\title{
Comparison of effectiveness disinfection of $2 \%$ glutaraldehyde and $4.8 \%$ chloroxylenol on tooth extraction instruments in the Department of Oral Maxillofacial Surgery, Faculty of Dentistry, University of North Sumatera
}

\author{
Ahyar Riza, ${ }^{*}$ Isnandar, Indra B. Siregar, Bernard
}

\section{Abstract}

Objective: To compare disinfecting effectiveness of $2 \%$ glutaraldehyde and $4.8 \%$ chloroxylenol on tooth extraction instruments at the Department of Oral Surgery, Faculty of Dentistry, University of North Sumatera.

Material and Methods: This was an experimental study with posttest only control group design approach. Purposive technique is applied to collect samples which are lower molar extraction forceps. In this study, sample were divided into 2 groups and each consisting of 18 instruments. The treatment group was treated with $2 \%$ glutaraldehyde while the control group was treated with $4.8 \%$ chloroxylenol. Each instrument was pre-cleaned using a brush, water and soap for both groups underwent the disinfection process.

Results: The results were statistically analyzed using Mann-Whitney Test. The comparison between glutaraldehyde and chloroxylenol showed a significant difference to the total bacteria count on instrument after disinfection $(p=0.014<0.05)$.

Conclusion: $2 \%$ glutaraldehyde was more effective than $4.8 \%$ chloroxylenol at disinfecting lower molar extraction forceps.
Department of Oral and Maxillofacial Surgery, Faculty of Dentistry, University of North Sumatera, Medan, Indonesia
*Corresponding to: Ahyar Riza, Department of Oral and Maxillofacial Surgery, Faculty of Dentistry, University of North Sumatera, Medan, Indonesia ahyar.riza@usu.ac.id

Received: 26 August 2018 Revised: 17 November 2018 Accepted: 29 November 2018 Available Online 1 December 2018

Keyword: Disinfection, Glutaraldehyde, Chloroxylenol, Forceps

Cite this Article: Riza A, Siregar IB, Isnandar, Bernard. 2018. Comparison of effectiveness disinfection of 2\% glutaraldehyde and $4.8 \%$ chloroxylenol on tooth extraction instruments in the Department of Oral Maxillofacial Surgery, Faculty of Dentistry, University of North Sumatera. Journal of Dentomaxillofacial Science 3(3): 169-171. D0I: 10.15562/jdmfs.v3i3.794

\section{Introduction}

Based on RISKESDAS 2013, Indonesian citizens have DMF-T index of 4.6 with the biggest component of missing teeth with score of 2.9, which means that each of Indonesian citizen has approximately three teeth that are extracted. ${ }^{1}$ An extraction procedure is high-risk for the transmission of infection because there is contact with blood and saliva of patients either directly or indirectly through contaminated instruments. ${ }^{2}$

Infection control can be done to reduce crosscontamination, such as disinfecting reusable instruments. Disinfection is divided into three categories which are high-level disinfection, intermediate level, and low level. High-level disinfection can eliminate all types of microorganism except spores. Glutaraldehyde and chloroxylenol are disinfectants that are widely used in the field of dentistry. Glutaraldehyde is a high-level disinfectant, whereas chloroxylenol is a intermediate level disinfectant. ${ }^{3,4}$ Glutaraldehyde works by changing the synthesis of proteins, DNA and RNA of microorganisms, while chloroxylenol change the cell wall and enzyme inactivation of microorganisms. ${ }^{5,6}$

A study about the disinfection effectiveness on orthodontic pliers showed that only $2 \%$ glutaraldehyde is able to decontaminate all pliers (100\%), where as ethyl alcohol and water with soap are unable to decontaminate all pliers in the study. ${ }^{4}$ A study about disinfection effectiveness on $\mathrm{x}$-ray equipment and accessories showed $4.8 \%$ chloroxylenol and $2 \%$ dichloroxylenol have the same efficacy which is fail to decontaminate $4.9 \%$ of the total sample. $^{7}$

This study aimed to compare disinfecting effectiveness of $2 \%$ glutaraldehyde and $4.8 \%$ chloroxylenol on tooth extraction instruments that are categorized as critical items, items that are high-risk of causing infection because it penetrates to sterile tissues located under skin or mucosa membrane. ${ }^{3}$

\section{Material and Methods}

This study is an experimental with post-only control group design approach. Sampling method used in this study is purposive sampling and used lower molar extraction forceps in the Department of Oral Maxillofacial Surgery, Faculty of Dentistry, University of North Sumatera as sample. In this study, samples are divided into two groups, the treatment group and control group, that consist of 18 instruments each. A $2 \%$ glutaraldehyde solution 
was used in the treatment group and a $4.8 \%$ chloroxylenol solution was used in the control group.

Previously used lower molar extraction forceps were first cleaned with a brush, water and soap to eliminate visible blood and saliva on the forceps before disinfection. The forceps were then immersed into a container that contained $250 \mathrm{~mL}$ of disinfectant solution for 1 hour for both groups. The forceps were removed from disinfectant, rinsed with sterile aquades and dried with sterile gauze. The beak of forceps were immersed in $50 \mathrm{~mL}$ of saline for 5 minutes and the container was closed tightly and sent to a microbiology laboratory for bacterial cultivation and colony bacteria count.

\section{Table 1 Total plate count after disinfection}

\begin{tabular}{|c|c|c|}
\hline \multirow{2}{*}{ No } & \multicolumn{2}{|c|}{ Total Plate Count (103 CFU/mL) } \\
\hline & $2 \%$ glutaraldehyde & $4.8 \%$ chloroxylenol \\
\hline 1 & 0 & 0 \\
\hline 2 & 0 & 0 \\
\hline 3 & 0 & 0 \\
\hline 4 & 0 & 168 \\
\hline 5 & 0 & 0 \\
\hline 6 & 0 & 812 \\
\hline 7 & 0 & 158 \\
\hline 8 & 0 & 22 \\
\hline 9 & 0 & 0 \\
\hline 10 & 0 & 234 \\
\hline 11 & 0 & 0 \\
\hline 12 & 0 & 1 \\
\hline 13 & 8 & 0 \\
\hline 14 & 0 & 0 \\
\hline 15 & 0 & 0 \\
\hline 16 & 0 & 0 \\
\hline 17 & 0 & 90 \\
\hline 18 & 0 & 0 \\
\hline
\end{tabular}

Table 2 Mean result of total plate count of two groups

\begin{tabular}{lccc}
\hline Group & Sample & $\begin{array}{c}\text { Mean } \\
\text { (CFU/mL) }\end{array}$ & $\begin{array}{c}\text { Standard deviation } \\
\text { (CFU/mL) }\end{array}$ \\
\hline 2\% glutaraldehyde & 18 & 444.44 & 1.885 .62 \\
$4.8 \%$ chloroxylenol & 18 & 82.500 & 196.043 \\
\hline
\end{tabular}

Table 3 Normality test and statistical test of two groups

\begin{tabular}{lccc}
\hline Group & $\begin{array}{c}\text { Mean } \pm \text { Standard } \\
\text { Deviation (CFU/mL) }\end{array}$ & $\begin{array}{c}\text { P-value } \\
\text { (Shapiro-Wilk) }\end{array}$ & $\begin{array}{c}\text { P-value } \\
\text { (Mann Whitney) }\end{array}$ \\
\hline 2\% glutaraldehyde & $444.44 \pm 1.885 .62$ & 0.000 & 0.014 \\
$4.8 \%$ chloroxylenol & $82.500 \pm 196.043$ & 0.000 & \\
\hline
\end{tabular}

The sample solutions were diluted to $10^{-3}$ and cultivated on an agar plate and incubated for 24 hours. The number of bacterial colonies formed on the agar plate were counted using bacteria colony counter. From the bacteria colonized on plate count agarose was taken to make pure culture of the colony on nutrient agar and incubated for 24 hours. Pure culture was used to observe the gram type of the bacteria. Data processing was done with computerized analysis using MannWhitney test.

\section{Results}

This study showed that out of 36 lower molar extraction forceps, 18 were disinfected using $2 \%$ glutaraldehyde and 18 were disinfected with $4.8 \%$ chloroxylenol. Out of 18 forceps disinfected using $2 \%$ glutaraldehyde, 1 (5.56\%) was still contaminated by bacterial colonies formed on the agar plate which is $8.10^{3} \mathrm{CFU} / \mathrm{mL}$. Out of 18 forceps disinfected using $4.8 \%$ chloroxylenol, $7(38.89 \%)$ samples were still contaminated with the maximum score of $812.10^{3} \mathrm{CFU} / \mathrm{mL}$ table 1 . The mean results of each group obtained are $444.44 \pm 1.885 .62 \mathrm{CFU} / \mathrm{mL}$ for treatment group and $82.500 \pm 196.043 \mathrm{CFU} / \mathrm{mL}$ for control group table 2. The Shapiro-Wilk test was conducted to determine the normality of data and the result was not distributed normally, and then the MannWhitney test is used table 3 .

The Mann-Whitney test was conducted to determine whether there are significant differences between disinfecting lower molar extraction forceps using $2 \%$ glutaraldehyde and $4.8 \%$ chloroxylenol. The result of Mann-Whitney test between the treatment group and control group resulted in a p-value of 0.014 that was $<0.05$ table 3 . This result showed that there was a significant difference in the number of bacterial colonies between the glutaraldehyde and chloroxylenol post disinfection. Besides the number of bacterial colonies, this study also observed the gram type of bacteria remaining on the sample and found that all the contaminated samples were gram-negative bacteria.

\section{Discussion}

The disinfectants tested in this study were $2 \%$ glutaraldehyde and $4.8 \%$ chloroxylenol. Glutaraldehyde has been used widely as high-level disinfectant for over 30 years because of its favourable materials compatibility, cheaper cost and immersion time is longer. Chloroxylenol is also widely used in the household and in medical field as antiseptic and disinfectant as well as a 
surface/environmental cleaner. ${ }^{8,9}$ The Spaulding classification describes three instrument/risk categories (critical, semi-critical and non-critical), each of which has specific reprocessing requirements. According to the Spaulding classification, lower molar extraction forceps are classified as critical items, objects that enter sterile tissue or vascular system should be sterile because any microbial contamination could result in disease transmission..$^{3,10}$

The result from the 13th glutaraldehyde (G13) sample group was $8.10^{3} \mathrm{CFU} / \mathrm{mL}$, where this is the only sample that still contaminated after disinfection with glutaraldehyde. This may be caused by some factors, such as patient oral hygiene status and pathological findings such as severe caries, periodontal disease, pulp necrosis or abscess during tooth extraction. Recent studies showed Streptococcus mutans is frequently isolated from caries lesions, non-mutans streptococcus, actinomyces, lactobacillus and bifidobacterium were from dental biofilms covering white-spot lesions. Acute abscess frequently caused by caries, trauma and failed root canal treatment. In dental abscess culture, usually polymicrobial were found including streptococcus viridans, prevotella sp. and fusobacterium sp. A recent study showed bacteroides and porphyromonas sp. were found on the abscess culture as well. Treponema sp. is an obligate anaerobes, helix-shaped and usually related to periodontal disease, as well as found in dental acute abscess. ${ }^{11,12}$ Besides that, environmental sterility during the sampling procedures and bacterial cultivation procedure in laboratory and operator negligence could increase number of bacteria colonies cultivated.

The chloroxylenol group showed lower disinfection effectiveness than the glutaraldehyde group. There were 7 samples still contaminated after the disinfection which was $\mathrm{C} 4, \mathrm{C} 6, \mathrm{C} 7, \mathrm{C} 8, \mathrm{C} 10, \mathrm{C} 12$ and C17. A number of bacterial colonies were mostly higher in this group, at the maximum of $812.10^{3} \mathrm{CFU} / \mathrm{mL}$. It is because chloroxylenol is an intermediate level disinfectant, while glutaraldehyde is a high-level disinfectant. Patient oral hygiene status and pathological findings along with environmental sterility and operator negligence could cause the number of bacterial colonies cultivated to increase.

In this study, observation of the gram type bacteria is also done to see whether it is gram-positive orgram-negative. After the observation of the 8 contaminated samples, all of them were stained red which means shows gram-negative bacteria.

\section{Conclusion}

According to the results presented above, it can be concluded that $2 \%$ glutaraldehyde is more effective at disinfecting lower molar extraction forceps than $4.8 \%$ chloroxylenol, therefore $2 \%$ glutaraldehyde is recommended to be used for disinfecting lower molar extraction forceps.

\section{Acknowledgment}

The government of the study country and the World Health Organization did not influence this analysis nor the decision to publish these findings. The study did not receive any financial support.

\section{Conflict of Interest}

The authors report no conflict of interest.

\section{References}

1. Jacob MTC. Biofilms, a new approach to the microbiology of dental plaque. Odontol 2006;94: 1-9

2. Suleh MM, Vowor VNS, Mintjelungan CN. Pencegahan dan pengendalian infeksi silang pada tindakan ekstraksi gigi di rumah sakit gigi dan mulut pspdg fk unsrat. J e-Gigi (eG) 2015;3: 587-588.

3. Rutala WA, Weber DJ. Disinfection and sterilization: an overview. American J Infection Control 2013;41: S2-S5.

4. Almeida CMF, Carvalho AS, Duarte DA. Evaluation of disinfection methods of orthodontic pliers. Dent Press J Orthod 2012;17: 106-109.

5. Juan MR, Herrin A, Concert C, et al. Guideline for use of high-level disinfectants \& sterilants for reprocessing flexible gastrointestinal endoscopes. Chicago: SGNA; 2013. p. 9-12.

6. Marsh PD. Controlling the oral biofilm with antimicrobials. J Dentist 2010;38: S11-S15.

7. Ochie K, Ohagwu CC. Contamination of X-ray equipment and accessories with nosocomial bacteria and the effectiveness of common disinfecting agent. African J Basic \& Appl Sci 2009;1: 31-35.

8. Venkatesh SP, Kuthandapani S, Marudavanan R, etal. A comparative study of efficacy of disinfectants used for flexible endoscopes: glutaraldehyde versus orthophthalaldehyde. Sch J Appl Med Sci 2014;2: 1408-1412.

9. El-Mahmood AM, Doughari JH. Effect of Dettol on viability of some microorganisms associated with nosocomial infections. African J Biotechnol 2008;7: 1554-1562.

10. Thaweboon $S$, Thaweboon B. In vitro antimicrobial activity of ocimum americanum 1 . essential oil against oral microorganism. Southeast Asian J Trop Med Public Health 2009;40: 1025-1033.

11. Takahashi N, Nyvad B. The role of bacteria in the caries process: ecological perspectives. J Dent Res 2011;90: 294-303.

12. Robertson D, Smith AJ. The microbiology of the acute dental abscess. J Med Microbiol 2009;58: 155-162.

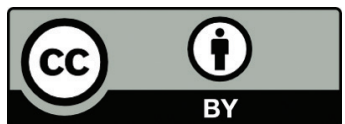

This work is licensed under a Creative Commons Attribution 